\title{
Correction to: Aotearoa New Zealand's New National History Curriculum and Histories of Mourning
}

\author{
Avril Bell $^{1}$ (D) Elizabeth Russell ${ }^{1}$ \\ Published online: 15 February 2022 \\ (c) The Author(s) under exclusive license to New Zealand \\ Association for Research in Education 2022
}

\section{Correction to: New Zealand Journal of Educational Studies https://doi.org/10.1007/s40841-021-00231-2}

The article Aotearoa New Zealand's New National History Curriculum and Histories of Mourning, written by Avril Bell and Elizabeth Russell, was originally published electronically on the publisher's internet portal on 24 November, 2021 without open access.

With the author(s)' decision to opt for Open Choice the copyright of the article changed on 02 March, 2022 to (C) The Author(s).

Open Access This article is licensed under a Creative Commons Attribution 4.0 International License, which permits use, sharing, adaptation, distribution and reproduction in any medium or format, as long as you give appropriate credit to the original author(s) and the source, provide a link to the Creative Commons licence, and indicate if changes were made.

The images or other third party material in this article are included in the article's Creative Commons licence, unless indicated otherwise in a credit line to the material. If material is not included in the article's Creative Commons licence and your intended use is not permitted by statutory regulation or exceeds the permitted use, you will need to obtain permission directly from the copyright holder.

To view a copy of this licence, visit http://creativecommons.org/licenses/by/4.0/.

Open Access This article is licensed under a Creative Commons Attribution 4.0 International License, which permits use, sharing, adaptation, distribution and reproduction in any medium or format, as long as you give appropriate credit to the original author(s) and the source, provide a link to the Creative

The original article can be found online at https://doi.org/10.1007/s40841-021-00231-2.

Avril Bell

a.bell@auckland.ac.nz

1 University of Auckland, Sociology, Auckland, New Zealand 
Commons licence, and indicate if changes were made. The images or other third party material in this article are included in the article's Creative Commons licence, unless indicated otherwise in a credit line to the material. If material is not included in the article's Creative Commons licence and your intended use is not permitted by statutory regulation or exceeds the permitted use, you will need to obtain permission directly from the copyright holder. To view a copy of this licence, visit http://creativecommons.org/ licenses/by/4.0/.

Publisher's Note Springer Nature remains neutral with regard to jurisdictional claims in published maps and institutional affiliations. 